\title{
Teaching Mild Mentally Retarded Children using Augmented Reality
}

\author{
Suprih Widodo \\ Universitas Pendidikan Indonesia, Indonesia \\ Nur Azizah \\ Universitas Pendidikan Indonesia, Indonesia
}

Trisno Ikhwanudin

Postgraduate Program, Mathematics Education Department, Universitas Pendidikan Indonesia, Bandung, Indonesia

\begin{abstract}
Every child has the right to get an education, including mild mentally retarded children. As like normal children, mild mentally retarded children need education that can help their growth and development in accordance with their potential. However, learning media for mild mentally retarded children still have several obstacles, one of which is object recognition. Object recognition for mild mentally retarded children usually uses 2-dimensional objects that are difficult to recognize. In addition, when using 2-dimensional objects not all aspects of development can be developed properly. The purpose of this study is to provide an overview of the use of augmented reality in developing various aspects of development in mild mentally retarded children. The methodology in this study is qualitative descriptive. Data collection techniques used observation and interviews with mild mentally retarded children and one special teacher in West Java, Indonesia. Data were analyzed through several stages, namely data reduction, data presentation, data conclusions, and data validation using triangulation. The results of the study show that using the augmented reality technology, the mild mentally retarded children can be easier to recognize an object. In addition, the use of augmented reality can develop various aspects of development in mild mentally retarded children ranging from moral and religious values, cognitive, language, physical-motoric, social emotional, and artistic. Special schools or inclusive schools can utilize augmented reality as a learning medium in introducing objects to mild mentally retarded children.
\end{abstract}

Keywords: Augmented Reality, Mild Mentally Retarded Children, Developmental Aspects. 


\section{Introduction}

Every child is a unique individual and has a different pattern of development, so that requires different treatment. Data on the number of children with special needs in Indonesia reaches 1.6 million (BPS, 2017). Children with special needs are not limited to mentally retarded children (Heward and Wood, 2018). Children with special needs consist of various disorders namely visual impairments (blind), impaired intellectual intelligence and adaptation to the environment (mental retardation), hearing loss (deaf), motor disorders (involuntary impairment), emotional disorders, learning difficulties, behavioral disorders, and health problems.

The American Association on Intellectual and Developmental Disabilities (AAIDD) states that "intellectual disability is characterized by significant limitations in both intellectual functioning and adaptive behavior expressed in conceptual, social, and practical adaptive skills. This disability originates before age 18" (in Hallahan, et al., 2009, p. 147). Children with mental retardation are a condition of children whose intelligence is far below the average and characterized by limited intelligence and inadequacy in social communication (Atmajaya, 2017).

Hallahan, Kauffman, and Pullen (2009) states that mentally retarded children are a classification used to determine individuals with IQs ranging from 50-70. Mild mentally retarded children are able to read, write, simple counting with guidance from parents, teachers and the closest person. The population in Indonesia which has intellectual disability is 62,011 people, $2.5 \%$ of children affected by very severe mental retardation, $2.8 \%$ of severely retarded children, severely mentally retarded children are called profound debile imbisiles as much as $2.6 \%$ and mild mentally retarded children are $3.5 \%$ and the rest are called slow learner children (Depdiknas, 2009).

Dick and Carey (1990) define learning as a series of structured and planned events or activities utilizing one or several types of media. Mild mentally retarded children have the potential to be developed through the education process. Christian is a person with mental retardation who has extraordinary achievements, namely in 2011 Christian won a gold medal in the world mental retardation Olympics (Paralympic) held in Greece for swimming. In this case, mild mentally retarded children get education through the learning process.

Efendi (2009) states that mentally retarded children tend to think concrete, difficult to think, and experiencing difficulties in concentration. In line with Efendi, when the researchers make observations in one of the special school in West Java, the instructional media provided by the teacher for mild mentally retarded children is 2-dimensional objects. However, the learning media is considered still difficult for children to recognize the object. Mentally retarded children have not been able to think abstractly, they have difficulty when having to imagine an object that is not actually depicted or shown. 
In addition, the teacher only gives assignments to the child in the form of sticking, coloring, drawing, etc. The activities given by the teacher have not been able to develop developmental aspects in mild mentally retarded children ranging from aspects of religious, cognitive, language, physical-motoric, social emotional, and artistic moral values.

Based on this background, it is necessary to have learning media that can facilitate mild mentally retarded children in recognizing objects by changing an abstract to concrete. In addition, the developmental aspects of mild mentally retarded children also need to be developed through the media used. Therefore, the researchers provide a learning media that can be utilized by mild mentally retarded children, namely augmented reality technology.

Augmented reality (AR) is a synthesis of real and virtual imagery (Milgram, et al., 1994). Saputri (2017) stated that augmented reality is one of the rich interface technologies that is developing and has been implemented in many fields, one of which is education. Augmented reality in education has a positive impact, which is interesting for multi-modal learning, increasing accessibility of educational content, increasing student control of educational content, opening opportunities for collaborative learning, motivating students to be actively involved, and turning abstract into concrete (Atmajaya, 2017). Based on this explanation, augmented reality can be utilized in the field of education especially as a learning medium for mild mentally retarded children who are interactive, interesting, and able to change an abstraction into concrete ones. AR is $3 \mathrm{D}$ and more realistic or concrete than $2 \mathrm{D}$ media; because of that, AR is more recommended for mild mentally retarded children. With AR, mild mentally retarded children can easily understand an object and thus the developmental aspects of mild mentally retarded children can be developed properly.

The application of augmented reality technology to mild mentally retarded children supports one of the global trends, namely the industrial revolution in phase 4.0. In this phase, the internet of things or the automation and application of technology that relies on the internet and exchange of data. Facing the industrial revolution 4.0, special schools can utilize augmented reality technology as a learning media in introducing objects in a more concrete way.

\section{Literature Review}

The population of mentally retarded children occupies the highest number compared to the number of children with other limitations. America Association of Intellectual Developmental Disability (in Hallahan, 2009) stated that mentally retarded children are disabled children characterized by significant limitations both in intellectual function and adaptive behaviour. Based on The ICD-10 Classification of Mental and Behavioural Disorders, WHO, mental retardation is divided into 4 groups, namely: (1) Mild retardation (mild mental retardation) with IQ 50-69; (2) Moderate retardation with IQ 35-49; (3) Severe retardation with IQ 20-34; and (4) Profound retardation with IQ $<20$. 
Mild mentally retarded children according to the Binet Scale have IQs between 68-52, whereas according to the Weschler Scale have an IQ between 69-55 (WHO, 1998). Mild mentally retarded children are children who experience mental delays but can still be educated to receive new knowledge or skills. In line with this opinion, Hallahan, et al. (2009) state that mentally retarded children are a classification used to determine individuals with IQs ranging from 50-70.

In general, mild mentally retarded children do not experience physical disorders, which means they look like normal children in general. Page (in Apriyanto, 2012) describes the characteristics of mentally retarded children, That are experiencing learning difficulties in almost all subjects (reading, writing, arithmetic), lack of achievement, bad work habits, easy switching, lack of motor skills, and difficulty adjusting. In addition, the learning capacity is very limited, especially for abstract things. Even so, children in this group still have the ability in academics such as being able to read, to write, and simple counting. However, it still requires guidance and good education.

Mild mentally retarded children are children who are not able to take part in ordinary school programs, but still have abilities that can be developed through education even with less than optimal results (Efendi, 2006). Mild mentally retarded children can get education in special schools both public and private. In addition, mild mentally retarded children can also attend public schools and get inclusive education. Stubbs (2002) identifies the principle of inclusive education into several basic elements that enable inclusive education to be implemented, these elements include: (1) teacher attitudes that are positive for diversity; (2) promoted interactions in cooperative learning; (3) collaborative consultation between professionals; (4) living and learning in society; (5) partnership relations between schools and families; (6) independent learning and thinking; and (7) lifelong learning. Wherever mild mentally retarded children receive education both in special schools and in public schools still have to be given the widest access to develop aspects of their development.

Mild mentally retarded children get education through the learning process. Dick and Carey (1990) define learning as a series of structured and planned events or activities utilizing one or several types of media. It is important to know that there are various obstacles in the learning process in mild mentally retarded children. One obstacle exists in terms of cognitive, which tends to have concrete thinking skills, difficult to think, and experiencing difficulties in concentration (Efendi, 2009). It is necessary for the existence of learning media for mild mentally retarded children so that they can help recognize objects in a concrete way by utilizing the developing technology of augmented reality.

Augmented reality (AR) is a synthesis of real and virtual imagery (Milgram et al., 1994). Augmented reality which is a technology that combines the real world with cyberspace, which allows objects in cyberspace to be displayed with objects in the real world simultaneously, so this technology can be applied in various fields, including in the field of education (Krevelen \& Poelman, 2010). In line 
with this, Nazaruddin \& Efendi (2018) states that augmented reality can be used for learning for mentally retarded children. This learning application is more suitable for people with mental retardation because it can help improve memory.

In addition, augmented reality is a use of digital computers in real-time by using other special hardware and software to produce a simulation of the world or alternative environment, which is believed to be something real or true for users (Hincaoie, et al., 2012). The augmented reality has been applied in various fields of life, where augmented reality is used as an application concept that combines the physical world (real object) with the digital world, without changing the shape of the physical object. Introduction of objects (text and images) used to display various information about the object. Augmented reality as a cognitive system able to fully understand the perceptions of users (Boud, 1999).

Augmented reality in education has a positive impact, which is interesting for multi-modal learning, increasing accessibility of educational content, increasing student control of educational content, opening opportunities for collaborative learning, motivating students to be actively involved, and turning an abstract into concrete (Lulian, et al. 2010). There are several principles of augmented reality according to Azuma, et al. (2001), namely: (1) augmented reality is a combination of real and virtual worlds; (2) augmented reality runs interactively and real time; and (3) there is integration between 3-dimensional objects, namely virtual objects integrated in the real world.

Hautger (2014) divides 4 stages of augmented reality work, namely: (1) capture, take pictures (video capturing) using camera media directed at objects that are used as markers; (2) identification, identification of suitability of images captured in the capture process with marker images that have been configured with the system; (3) processing, the testing process from the results of the previous marker detection process to determine the position of storage of existing virtual content. The position of virtual content can be identified through markers or by tracking GPS depending on how the system is integrated; (4) visualization, virtual content is displayed. This content can be text, images, videos and $3 \mathrm{D}$ objects.

By applying augmented reality to learning, teachers or parents can create a more real learning atmosphere for students by displaying 3D objects, as well as improvising sounds and images that support the learning. In addition, mild mentally retarded children can easily understand a lesson and attract their focus and attention.

The augmented reality technology uses the quipper vision application that has many image objects such as animals, plants, transportation equipment and so on. This object is already available in the Quipper Vision application, meaning that users only need to print the images that have been provided for scanning in a smartphone or tablet. Kagohara, et al. (2013) stated that the use of tablets was able to accelerate mastery of the material. By using a smartphone or tablet, it is 
expected that mild mentally retarded children get the same opportunity as other normal children.

\section{Methods}

The method section describes the research methods used including research design, research subjects, and research procedure.

\section{Research Design}

The methodology in this study is qualitative descriptive. Qualitative research according to Bogdan and Taylor is a research procedure that produces descriptive data in the form of written or oral words from people and observable behavior (Moleong, 2010). Bogdan and Biklen (1982) state that qualitative research has a natural setting as a direct source of data and the researcher is a key instrument. The point is that researchers are the main data collection tool.

\section{Research Subjects}

The subject of research is two special needs students, one female (student A), and another student is male (student B). The two students are in grade 4 of Special Needs School of Purwakarta, West Java. They are given different pictures of animals, picture of cow for student A and picture of lion for student B. The authors also interviewed one teacher of Special Needs School of Purwakarta.

\section{Research Procedures}

The technique of collecting data uses observation and interviews. Data collection techniques in qualitative research in general can be grouped into two methods of data collection techniques that are interactive and non-interactive. In this study the authors uses interactive techniques including observation and interviews. The observation is participant observation. Participant observation is a deep observation by blending into the middle of the research subject. Marshall (2011) states that through observation, researchers learn about the behavior and meaning of the behavior. Observations were made to determine the activities of mild mentally retarded children in using augmented reality as a learning medium. Observations are carried out in an unstructured way. Whereas interviews according to Sugiyono (2015) are data collection techniques if researchers want to conduct a preliminary study to find problems that must be studied or if researchers want to know things from respondents who are more in-depth.

Interview as a technique of collecting data by means of question and answer that is carried out systematically based on certain objectives. Interviews were conducted on mild mentally retarded children and teachers in one of the special school in West Java. Through interviews, efforts are made to dig deeper information about mild mentally retarded children. Interviews are conducted in a structured and face to face. Questions asked to mild mentally retarded children by the conditions in the field, that means the questions are natural. Questions raised in the form of questions about the child's identity and questions that support research. The questionnaire of the interview is as follows: 


\section{Questions for student A}

What is your name? Where is the house? Who accompanied you to go to school?

Take a look, what picture is that? (Student A: "Cow")

Want to color the cow using what color?

What does the cow eat?

What color is cow milk?

Mention the limbs of a cow?

Try pointing, which one is the eye of a cow? How many eyes are there?

How many feet does a cow have?

Who created Cows?

\section{Questions for student B}

What is your name? Where is the house? Who accompanied you to go to school?

Take a look, what picture is that? (Student B: "Lion")

Want to color the lion using what color?

What does the lion eat?

Mention the limbs of a lion?

Try pointing, which one is the tail of lion?

How many feet does a lion have?

Who created Lions?

\section{Questions for teacher}

Usually, mild mentally retarded children can arrange how many pieces of the puzzle?

For a grade 4 child with mild intellectual disability, equivalent to what class of regular students?

When studying, do they follow the teacher's instructions?

Data obtained from observations and interviews are analyzed. At this stage the author describes what is seen, heard, felt and asked. The author reduces all information that has been obtained by sorting data or choosing which data is interesting, important, useful and new. Based on these considerations, the data are then grouped into various categories that are determined as the focus of the study.

The next stage is the presentation of data, namely presenting information obtained from the data reduction process, then organized and presented with a narrative text model. The next stage is conclusions and verification of data that has been patterned, focused, and arranged systematically, then concluded, for the next search for new data, as a test of the tentative conclusions obtained.

The last step is data validation using triangulation. Triangulation is a technique of collecting data that is combining the various techniques of collecting data and existing data sources. Researchers are involved with the daily activities of people who are being observed or used as research data sources. Triangulation is a technique of checking the validity of data that uses something else in comparing the results of interviews with the object of research (Moloeng, 2004). The goal is 
to check and compare the data. In line with this opinion, Creswell (2014) stated that data triangulation aims to compare answers between participants and experiences among fellow researchers who collected data.

\section{Findings and Discussion}

The findings of this study can be classified into the following themes and subthemes:

Table 1: Themes and subthemes of findings

\begin{tabular}{|l|l|l|}
\hline No & $\begin{array}{l}\text { Themes (Aspect of } \\
\text { development) }\end{array}$ & Subthemes \\
\hline 1 & cognitive & $\begin{array}{l}\text { easier to recognize an image object, knowing } \\
\text { various colors, critical thinking skills }\end{array}$ \\
\hline 2. & moral and religious values & $\begin{array}{l}\text { knowing God, noble character, respect and care } \\
\text { of animals, religious education. }\end{array}$ \\
\hline 3 & language & $\begin{array}{l}\text { voice recognition, adding vocabulary, } \\
\text { communication, speaking }\end{array}$ \\
\hline 4 & social emotional & $\begin{array}{l}\text { patient waiting for their turn, appreciating the } \\
\text { work of their friends, expressing emotional } \\
\text { expressions }\end{array}$ \\
\hline 5 & physical-motoric & gross motor, fine motor \\
\hline 6 & artistic & various colours in using augmented reality \\
\hline
\end{tabular}

Following are the details of these findings. In this research, mentally retarded children are directed to give color to the puzzle image. The process of giving color is free means that there is no compulsion in the use of color. The goal is that the child's imagination develops well. After the coloring process is complete, open the quiver vision application and scan the puzzle image. A 3dimensional image appears and the child sees an image that was originally 2 dimensional and difficult to understand, now the animal's image looks like it is real. The color of the scanning results is the same as the 2-dimensional image that has been colored by mild mentally retarded children. The process is illustrated in the figure 1 . 


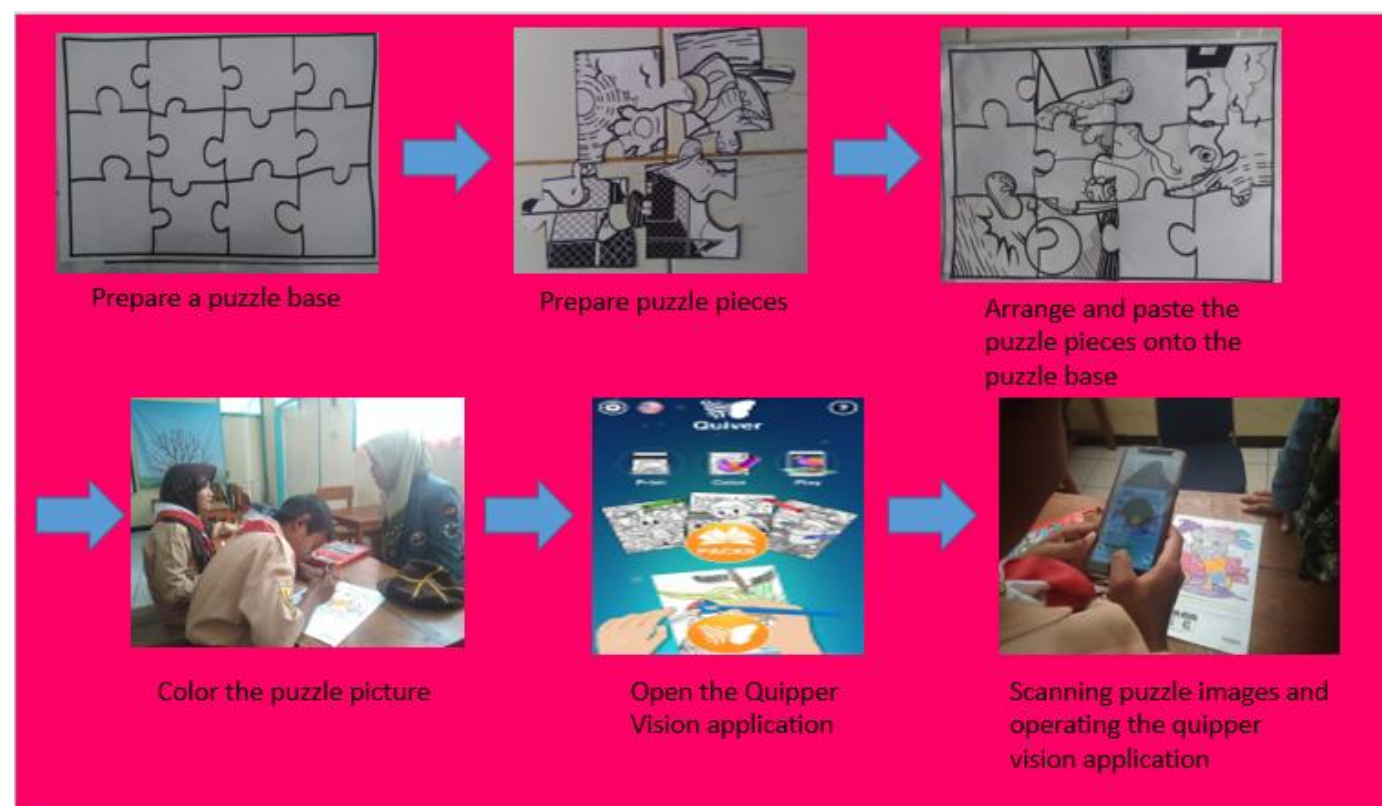

Figure 1: Utilization of augmented reality in mildly retarded children

After utilizing augmented reality as a learning medium for mild mentally retarded children, cognitive development in children is increasingly developing. The cognitive domain is the domain that includes mental activities (brain) or intellectual abilities, which are needed to perform various mental activities (thinking, reasoning, and solving problems) (Robbins \& Judge, 2009). The cognitive domain in children with mental retardation develops when children are easier to recognize an image object that they have colored. When the researcher asked "What is this picture?", The two mild mentally retarded children answered "This is a picture of a cow". In addition, when the researcher asked mild mentally retarded children which were the eyes of cattle, they were able to show the location of the two cow eyes that appeared on the smartphone screen. Likewise with the limbs of the animal shown. That is, children can identify various forms of animals such as eyes, nose, mouth, feet, hands, and other types of limbs.

Children can know various colors. Before the child projects the image through the quiver vision application, children are directed to color images of animals that have been provided. In the coloring process, the child is free to choose the color they want. That way children recognize various colors because mentally retarded children have limitations in color selection, have unstable emotions, this can be seen when colored pencils are written with pressure full of emotional overflowing.

Critical thinking skills in mild mentally retarded children can be developed. Critical thinking is a part of high-level thinking because it involves the process of analysis, synthesis and evaluation. Angelo identified 5 critical thinking behaviors, namely: (1) analytical skills; (2) synthesis skills; (3) skills to recognize and solve problems; (4) summing up; (5) evaluating and evaluating. Child critical thinking skills can be trained when children arrange puzzle pieces into a complete form. This is seen when the writer gives a puzzle of 12 pieces and they 
are able to arrange it correctly even though it takes a short time. In line with what one special teacher said: "mild mentally retarded children are able to arrange 10-12 puzzle arrangements. The ability to arrange puzzles is given to mild mentally retarded children with the aim of training critical thinking skills."

In addition to the cognitive aspects, aspects of moral and religious values are also developed when teachers utilize augmented reality technology. This can be seen when the researcher shows the results of scanning 3-dimensional images on a smartphone or tablet and the child sees objects that are displayed such as animals, plants and so on. After that, the author stimulated mild mentally retarded children with several questions such as: "what do you see, what animal?", then the child answered: "cow". The author continues with the statement: "cow is one of the animals created by God and we must love animals as creatures of God". In this case the child is introduced that our fellow beings also need to respect and care for them.

It is very important that moral and religious aspects be developed in mild mentally retarded children. Moral and religious aspects include the introduction, understanding, and developing of religious values, as well as the practice of those values in the lives of individuals or community collectives. In the end it aims to optimize the various potentials possessed by human beings whose actualization reflects the dignity of God.

The use of augmented reality can also support religious education. The purpose of religious education is to increase spiritual potential and shape students to become human beings who believe and fear God the Almighty and have a noble character. Noble morals include ethics, character, and morals as manifestations of religious education.

In addition to cognitive aspects and religious moral values, language development in mild mentally retarded children was also developed. This can be seen when the child can find out the animal sounds projected into the quiver vision application. Besides being able to display image objects in 3 dimensions, this quiver vision application can also display audio or sound that matches the image. Example: a cow appears when projecting a cow image. There are several benefits that children get when interacting with animals according to Alach (2003), namely: (1) children learn to recognize and appreciate living things, he learns that living things need food, shelter and love; and (2) children learn to love animals, which in turn can foster a sense of affection for living things.

After the child sees the object that appears and listens to the sound of the object, the child can find out the name and sound of the animal, so that it can add to the child's vocabulary and develop aspects of language development in mild mentally retarded children. In addition, the teacher can stimulate the child with questions that are appropriate to the object displayed. For example: the object displayed is a cow, a child's stimulus with questions like, what animal is that? What color is the cow? How many legs of a cow? And other questions that led to communication between teachers and mild mentally retarded children. 
Communication ability is the main development area that is susceptible to obstacles in mentally retarded children and the most common reason for a child to get special education early to help with further development. Communication is a way to build a relationship between a human being and another human being. According to Hurlock (1997) communication means an exchange of thoughts and feelings in which exchange can be carried out with every form of language such as cues, emotional expressions, speech, or written language, but the most common and most effective communication is by speaking. Therefore it needs to be stimulated and developed so that the developmental aspects of the language of mild mentally retardation children can develop.

Ingall (1978) revealed that the language skills of mentally retarded children using ITPA (Illinois Test of Psycholinguistic Abilities), showed that (1) mentally retarded children acquired language skills basically the same as normal children; (2) the speed of mentally retarded children in acquiring language skills is much lower than in normal children; (3) most mentally retarded children cannot achieve perfect language skills; (4) the language development of mentally retarded children is very late compared to normal children, even in the same MA; (5) mentally retarded children experience certain difficulties in mastering grammar; (6) mental retardation is concrete; (7) mentally retarded children cannot use compound sentences, they will use many single sentences.

McLean and Synder (in Sunardi and Sunaryo, 2006) in their study stated that mentally retarded children tend to experience difficulties in language skills, including morphology, syntax, and semantics. Mentally retarded children have a tendency to actively communicate even though deficit language skills make information difficult to understand (Yohana, 2014). When communicating verbally, children's language is poorly understood by other students. This is because the words spoken by the child are less clear. In line with what the researcher heard when mild mentally retarded children say some answers to the questions. Seen the words spoken are less clear and tend not to speak much using verbal language. This is because cognitive development is hampered making mentally retarded children develop skills in giving and receiving nonverbal communication (Porter, 2002).

In terms of communication, children are not able to distinguish between languages for their friends. Pratiwi, et al. (2013) state that speaking is the ability to say sounds or words to express, convey thoughts and feelings. Every language skill is closely related to the thought processes underlying the language. A person's language reflects his mind. The more skilled someone is in speaking, the brighter and clearer the mind will be.

Skills can only be acquired and mastered by practice and lots of practice. Practicing language skills also means thinking skills. The statement shows that the higher a person's intelligence, the more skilful his or her abilities will be. And vice versa, the lower a person's intelligence, the lower his ability to speak. Thus it can be said, the more severe the impairment, the lower the ability to 
speak. The vocabulary or sentence used in everyday life is concrete. This means that the child can know the new vocabulary when he sees the object shown or the object he sees.

The next development that develops when implementing augmented reality is social emotional. Children's social emotional develop when they are able to be patient waiting for their turn the process of scanning 2-dimensional images into 3-dimensional objects using the smartphone/tablet provided. This can train mild mentally retarded children to appreciate the work of their friends. According to the American Association on Intellectual and Developmental Disabilities (in Hallahan, et al. 2009), it is stated that mental retardation is characterized by clear limitations in both intellectual function and adaptive behavior that is shown conceptually, socially, and the application of adaptive abilities. This limitation appears before the age of 18 years. It can be concluded that mild mentally retarded children not only have limitations in intellectual functioning but also the social and emotional development of children also needs to be well developed.

These obstacles are usually coupled with the emergence of problems related to children's adaptive behavior, especially those related to social skills (Delphie, 2009). The main factor that makes mentally retarded children difficult to make social adjustments in certain activities or work environment is socio-emotional factors. These socio-emotional factors include feelings of anxiety, feelings of dissatisfaction caused by others (envy), aggression (aggression), and negative attitudes towards an authority (attitude toward authority) (Department of Health, Education and Welfare USA in Delphie, 2005). The social-emotional development of mild mentally retarded children is quite good. Seen when the child does not feel afraid when the researcher comes. They welcomed our presence and when asked they would answer. Although the answers they made were only a few words. Children are quite capable of expressing emotional expressions. When you are happy, your child will laugh. When sad, children are able to display sad faces. If the child is upset or angry, the child is able to display his upset face, which is sullen. When angry, children also usually stay in place and if invited to play, the child will refuse.

Self-adjustment is a variation in the activities of an organism to overcome an obstacle and satisfy needs and emphasize a harmonious relationship with the physical and social environment (Chaplin, 2006). According to May Lwin, et al. (2008) there are several indicators to be a benchmark for social skills possessed by a child of low and high levels, as follows: (1) indicators of low social skills if children do not like to mingle or play with other children prefer to be alone, withdraw from others, especially during children's parties, seize and take toys from other children, beat and kick other children and regularly engage in fights, do not like to take turns, do not like to share and are very possessive (accentuating ownership) of his toys, and being aggressive and screaming when he doesn't get what he wants; (2) indicator of high social skills, if children make friends and get acquainted easily, like to be around other people, curious about others and friendly to strangers, use with their toys and share sweets with 
friends, succumb to children another child and know how to wait for his turn while playing.

Another important aspect of development is the physical-motoric aspect, divided into gross motor and fine motor. The physical motor aspect that is most highlighted in the use of augmented reality is fine motors. When the process of coloring puzzle images, children's fine motor skills are developed. In line with this, Sukintaka (2001) reveals that fine motor skills can be interpreted as the ability of a child to carry out activities related to the control of movement and the ability to focus attention. According to Saputra (2005), the fine motor is: (1) capable of functioning small muscles such as the movement of the fingers; (2) able to coordinate the speed of the hands and eyes; and (3) able to control emotions. The fine motor development of children with mental retardation is important to develop considering the many impacts that will occur when the child is not stimulated by the development of fine motor skills.

The fine motor development of mild mentally retarded children can be developed through the use of augmented reality when the child arranges puzzles before the 2-dimensional image is scanned. When compiling a puzzle the child uses both hands to arrange, use glue and attach it to the puzzle. In addition, to compiling puzzles, when operating augmented reality using a tablet or smartphone, can also develop aspects of fine motor development for mild mentally retarded children.

Kephart (in Rochyadi and Alimin, 2005) believes that all one's actions have a basis, namely motor. It is from these motoric that humans make generalizations for doing further actions. Obstacles to fine motor skills in mild mentally retarded children are seen from stiff and non-aiming hand movements. The low motor skills of children with mental retardation cause children difficulty in carrying out daily activities.

The development of the art of mild mentally retarded children occurred when children use the various colours in using augmented reality. There is no compulsion in giving colour in order to develop the imagination of mentally retarded children. In addition, the use of colour in the image can also find out the child's feelings. Colour is directly related to feelings and emotions. For example, the colour red gives the impression of being angry, brave, strong, passionate, excited and challenging. Green colour gives the impression of cool, calm, fertile and natural. Yellow gives the impression of being warm, cheerful, and happy. When using colours on an object image, mentally retarded children tend to use colours that match the original colour of the object. Like when drawing cows they use white with black shades, like animal colours in general.

\section{Conclusion}

This research focused on the use of augmented reality in mild mentally retarded children is collaborated with puzzle media from image objects that will be scanned. Mild mentally retarded children are directed to arrange the composition of puzzle objects, stick to the puzzle of the puzzle and the colouring 
process of the object image. By utilizing the augmented reality technology of mild mentally retarded children, it is easier to recognize an object because objects that appear are not 2-dimensional but 3-dimensional images that are clearer and look more real. In addition, the use of augmented reality can develop various aspects of development in mild mentally retarded children ranging from moral and religious values, cognitive, language, physical-motoric, social emotional, and artistic. Recommendation of this research is special school can utilize augmented reality as a learning medium in introducing objects to mild mentally retarded children. Also, parents at home can use augmented reality as a learning medium for children. By utilizing augmented reality, it is expected that mild mentally retarded children get the same opportunities as other normal children in utilizing technology.

\section{References}

Apriyanto, N. (2012). Seluk-Beluk Tunagrahita \& Strategi Pembelajarannya [The Intricacies of Mentally Retarded and Its Learning Strategies]. Yogjakarta: Javalitera.

Atmajaya, D. (2017). Implementasi Augmented Reality untuk Pembelajaran Interaktif [Implementation of Augmented Reality for Interactive Learning], Jurnal Ilkom,9(2).

Azuma, R., Baillot, Y., Behringer, R., Feiner, S., Julier, S., \& MacIntyre, B. (2001). Recent advances in augmented reality, IEEE Computer Graphics and Applications, 21(6).

Badan Pusat Statistik. (2017). Statistik Indonesia 2017 [Indonesian Statistics 2017]. Jakarta: BPS.

Bogdan, R.C. \& Biklen, K. S. (1982). Qualitative Research for Education: An Introduction to Theory and Methods. Allyn and Bacon, Inc.: Boston London.

Boud, A. C., Haniff, D. J., et al. (1999). Virtual reality and augmented reality as a training tool for assembly tasks, in Proceedings IEEE International Conference on Information Visualization.

Chaplin, J. P. (2006). Kamus Lengkap Psikologi [Complete Dictionary of Psychology]. Jakarta: Raja Grafindo Pustaka.

Delphie, B. (2005). Bimbingan Konseling untuk Prilaku Non-Adaptif [Counseling Guidance for Non-Adaptive Behavior]. Bandung: Pustaka Bani Quraisy.

Delphie. B. (2009). Bimbingan Prilaku Adaptif: Anak dengan Hendaya Perkembangan Fungsional [Adaptive Behavior Guidance: Children with Functional Development Obstacle]. Sleman: PT Intan Sejati Klaten.

Depdiknas. (2009). Data Sekolah Luar Biasa [Special School Data]. Jakarta: Depdiknas

Dick, W. and Carey, L. (1990). The Systematic Design of Instruction. USA: Harper Collins Publishers.

Efendi, M. (2006). Psikopedagogik anak berkelainan [Psychopedagogic children with disabilities]. Jakarta: Bumi Aksara.

Efendi, M. (2009). Pengantar Psikopedagogik anak berkelainan [Introduction to Psychopedagogic children with disabilities]. Jakarta: Bumi Aksara.

First Years: Na Tau Tuatahi. New Zealand Journal of Infant and Toddler Education, 5(1), 2527.

Hallahan, D.P., Kauffman, J.M., \& Pullen, P.C.. (2009). Exceptional Learners Eleventh Edition. New Jearsey: Pearson.

Heutger, M. \& Kückelhaus, M. (2014). Augmented Reality In Logistics Changing The Way We See Logistics-A DHL Perspective. Germany: DHL Customer Solutions \& Innovation. 
Heward C.L. (2018). Exceptional Children: An introduction to special education. Upper Saddle: Pearson.

Hincapié, M., Caponio, A., Rios, H., \& Mendívil, E.G. (2011). An introduction to Augmented Reality with applications in aeronautical maintenance. 2011 13th International Conference on Transparent Optical Networks, 1-4.

Hurlock, E. B. (1997). Perkembangan Anak [Child development]. Jakarta: Gramedia.

Ingalls, R.P. (1978). Mental Retardation: The Changing Outlook. New York: John Wiley \& Sons, Inc.

Kagohara, L. V. D. Meer, S. Ramdoss, M. F. O'Reilly, G. E. Lancioni, T. N. Davis, M. Rispoli, R. Lang, P. B. Marschik, D. Sutherland, V. A. (2013). Using iPods® and iPads ${ }^{\circledR}$ in teaching programs for individuals with developmental disabilities: A systematic review, Research in Developmental Disabilities, 34 (1), pp. 147-156.

Krevelen and Poelman. (2010). A Survey of Augmented Reality Technologies, Applications and Limitations, International Journal of Virtual Reality, 9 (2), pp. 121.

Lulian, R., et al. (2010). Augmented Reality in the Future of Education. Atlanta: Georgia Institute of Technology.

Marshall, C. \& Rossman, G. B. (2011). Primary Data Collection Methods Designing Qualitative Research. Los Angeles, CA: SAGE.

May Lwin, et al. (2008). Cara Mengembangkan Berbagai Komponen Kecerdasan [How to Develop Various Components of Intelligence]. Jakarta: PT. Macana Jaya Cemerlang.

Milgram, P., \& Kishino, F. (1994). Augmented Reality: A Class of Displays on the Reality-virtuality Continuum. Proceeding Telemanipulator and Telepresence Technologies, vol. 2351.

Moloeng, L.J. (2004). Metodologi Penelitian Kualitatif [Qualitative Research Methodology]. Bandung. PT Remaja Rosdakarya.

Nazaruddin and Efendi, M. (2018). The Book of Pop Up Augmented Reality to Increase Focus and Object Recognition Capabilities for Children with Autism, Journal of ICSAR, 2 (1), pp. 9-14.

Porter, L. (2002). Educating Young Children with Additional Need. Crowsnest: Allen \& Unwin.

Pratiwi, E., Halidjah, S., \& Salimi, A. (2013). Peningkatan Kemampuan Berbicara Dengan Menggunakan Media Gambar Berseri Pada Pembelajaran Bahasa Indonesia Kelas I SD [Increased Speaking Ability by Using Serial Image Media in Indonesian Language Learning for Class I Elementary Schools]. Jurnal Pendidikan dan Pembelajaran, 2 (12).

Robbins, S.P. \& Timothy A.J. (2009). Origanizational Behavior. USA: Pearson International Edition.

Rochyadi, E., \& Alimin, Z. (2005). Pengembangan Program Pembelajaran Individual bagi Anak Tunagrahita [Development of Individual Learning Programs for Children with Disabilities]. Jakarta: Departemen Pendidikan Nasional.

Saputra, Y. (2005). Perkembangan Gerak dan Belajar Gerak [Motion Development and Motion Learning]. Yogyakarta: Depdikbud.

Saputri, D. (2017). Penggunaan Augmented Reality untuk Meningkatkan Penguasaan Kosakata dan Hasil Belajar [Use of Augmented Reality to Improve Vocabulary Mastery and Learning Outcomes], Jusiti, 6 (1).

Stubbs. S. (2002). Inclusive Education Where There are Few Resources. The Atlas Allianc.

Sugiyono. (2015). Metode Penelitian Kombinasi [Mix Methods Research]. Bandung: Alfabeta.

Sukintaka. (2001). Teori Pendidikan Jasmani [Physical Education Theory]. Solo: Esa Grafika Apriyanto. 
Sunardi \& Sunaryo. (2006). Intervensi Dini Anak Berkebutuhan Khusus [Early Intervention of Children with Special Needs]. Bandung: Jurusan PLB FIP UPI.

WHO. (1998). Primary prevention of mental neurological and psychosocial disorders. Geneva: WHO.

Yohana, N. (2014). Perilaku Komunikasi Verbal Dan Nonverbal Anak Tunagrahita [Verbal and Nonverbal Communication Behavior of Children with Developmental Disabilities]. Bandung: UNPAD. 